\title{
LESSONS FROM THE BOER WAR
}

\section{Review of an article by Dr C. de Jong*}

Review of: Jay Stone and Erwin A. Schmidl, The Boer War and Military reforms, Volume 28 of the series "War and Society of East Central Europe", University Press of America, Lanham: New York - London, 1988, $345 \mathrm{pp}$.

Numerous studies exist of the lessons to be learnt from the Anglo-Boer War 1899-1902 by students of 20th Century Warfare. These studies date back from the days of that war up to the present. In many cases these studies are titled "Lessons from the Boer War". In the book under review Jay Stone examines the War's impact on Britain and Erwin Schmidl its effect in AustriaHungary. I shall confine this review to Stone's findings. According to him Britain entered the war full of self-confidence in the hope of terminating the conflict within a few weeks, but was totally unprepared. The reason was that the last war she waged against a European power was as long ago as 1855-56. That was the Crimean War against Russia. Thereafter she had fought only local, colonial wars against badly drilled, little disciplined and primitively armed non-European armies. Some of these used to attack in large hordes and were shot or ridden down en masse. This had happened recently at Omdurman in 1898 where Kitchener defeated the Sudanese. The British ultimately were victorious in all the colonial wars.

The war in South Africa, however, started with a series of serious defeats for Britain, culminating in "Black Week" (Magersfontein 11, Stormberg 12, Colenso 15 December 1899), followed by more reverses (Spioenkop 24 January, Vaalkrans 5-7 February 1900). Stone writes (1.c.p.44): The defeats of the "Black Week" collectively had a greater impact than Dunkirk (port of British retreat June 1940). Britain, at the peak of her powers, had been mauled by a nation of farmers. The many adversaries of Britain's power gloated because the defeats revealed serious weaknesses in the British army and its tactics. The Government and the Army immediately took measures to correct these defects. A long drawn-out process of military reforms started, which laid the foundation for Britain's preparedness in the First World War.

Stone's extensive survey of defects and of corrective measures during the war can be summarised under the following points:
1. Small Army. The British army was small and intended for the colonies. The Navy would protect the mother country. The regular army numbered 216000 men and with the reserves 667000 . Sometimes the army in India had to send troops to other colonies in trouble (p.4). There was no military conscription. Immediately after Black Week volunteers from the reserves in Britain and from the Dominions in South Africa, Canada, Australia and New Zealand were sent to the fronts in South Africa. At the end of the war almost 440000 soldiers were stationed in South Africa.

2. General Staff. The Secretary of War and his officials dominated Army affairs. The General Staff (GS) was small, subordinated and ill-informed, so that it was caught unawares when the war in South Africa broke out. The GS was decidedly understaffed for such a vast area as South Africa.

Stone explains that soon after the war started the GS was augmented with eminent specialists such as Henderson for intelligence, Girouard for railways and Benson for flying columns. Nevertheless, the GS remained small, although its influence increased during the war.

3. Rivalries. The high-ranking officers at the War Office and the GS were divided into two opposing camps: the veterans of African campaigns, led by G. Wolseley, and those of Asian campaigns, headed by F.S. Roberts. Initially the African group was in command in South Africa and Wolseley's choice, Buller, was commander-in-chief. A few days after Black Week he was superseded by Roberts as C-in-C. He gradually eliminated most of the ineffective officers, such as Buller, Gatacre and Baden Powell, but he retained some Wolseley-men of the initial war phase, such as Methuen, Ian Hamilton and McDonald.

4. Amateurs. Most British officers came from the aristocracy, earned low pay, behaved more like amateurs than professional soldiers and thought more of horsemanship and valour than of a knowledge of drill, tactics and examinations. They had little contact with the ordinary soldiers and left them to the tender mercies of noncommissioned officers (NCOs). They enjoyed comfort and 
sport, even during campaigns, and since the Napoleonic Wars the British army was notorious on account of the large quantity of baggage they hauled along with them.

The war in South Africa started in the same way, e.g. with Buller's many cases of champagne, disguised as castor-oil. But according to Stone, Roberts and Kitchener changed the situation. They reduced the quantity of luggage drastically and sent unsoldierly gentlemen home. The Boer War virtually brought to an end the era of the amateur army-officer in Britain.

5. The Ordinary Soldier. The common British soldier was drilled to obey commands; not to think or to show initiative. This was to be a great disadvantage in the Boer War. Because of their conspicious dress and behaviour, many British officers were shot and as there was no-one to lead them the soldiers were helpless. Soon, however, they were drilled to act on their own initiative and care for themselves, to set their rifle sights as they thought fit, to seek cover and camouflage, to advance by crawling and making short bounds instead of standing or marching in formation, and to fire individually instead of in volleys with sights set after each command.

6. Ordnance and Small Arms. Initially British ordnance and rifles did not have the same range as the new Boer guns of Krupp and Creuzot and the Mauser rifles with smokeless powder. The British had fewer quickfiring Maxim-Nordenfeldts (pompoms) than the Boers. The British artillery was initially mounted in open terrain and in batteries of 6 guns, which fired simultaneously at one target. In contrast, the Boers dispersed their fewer guns and mounted them behind hills. They were well camouflaged and, when necessary, frequently moved to other designated positions. They were very effective. Stone praises Boer gunnery, with their Creuzots of Long Toms, but omits to mention that a third or half of the heavy Creuzot shells did not explode, which reduced the Long Tom's effectiveness.

He describes how the British artillery soon made up for its shortcomings. Long-range guns were ordered, more howitzers for attacking deep trenches, more pompoms and the first machineguns were introduced. Attention was given to more details, e.g. the gunshield to protect the exposed artillerymen. Following the example set by the
Boers, the British divided batteries into sections, firing independently, covering and camouflaging the pieces and sometimes dispersing them.

7. Tactics. Initially the British tactics were to launch direct, massive attacks in dense or late opening lines along a relatively small front. They preferred night marches before the assault, after the example of Wolseley at Tell-el-Kabir, Egypt 1882. But these successes could not be repeated in the face of the exceedingly strong firepower of Boers' repeating Mausers with smokeless power ${ }^{1}$. Heavy losses and defeats were the result of these tactics. Night marches, such as at Nicholson's Nek, Magersfontein and Stormberg led to disasters. The aim of the British was to engage in hand-to-hand-fighting, the infantry with the bayonet, the cavalry with lance and sabre. But the Boers disliked cold steel, which was the way savages fought, and they usually retreated before hand-to-hand-fighting could start.

Roberts did away with these tactics. He discarded the lance and sabre with the cavalry, but the infantry retained the bayonet. $\mathrm{He}$ ordered advances in more open and thinner lines and in alternating bounds tactics which had already been introduced piecemeal. He replaced direct fronial attacks by outflanking movements, which no Boer commando could withstand for long. The cavalry had to go over to reconnaissance work instead of shock tactics and charges and the lance and sabre were replaced by rifles.

8. Mobility. At the beginning of the war the British infantryman and cavalry horse were over-burdened. The cavalry horse had to carry 450 pounds, the Boer pony much less - 250 pounds (Stone, p.92). I suppose the horseman included. All fighting Boers were mounted. They could easily escape from the British infantry and also from their heavily burdened and quickly tired cavalry horses. When the war broke out, the GS preferred infantry to mounted troops - to their cost.

When Roberts arrived in South Africa he reduced the weight of equipment of the infantryman and cavalryman substantially. $\mathrm{He}$ introduced the Mounted Infantry (MI) already in existence, in small numbers - to keep up with the very mobile Boers and to fight the Boers in their own way, on foot as dismounted horsemen. The MI were a mixed lot, ridiculed by the infantry who aver- 
red that they could not march and were encumbered with their mounts, and by the cavalry who maintained that the $\mathrm{Ml}$ were poor horsemen and neglected their steeds - which, to a large extent, was true. But Stone agrees there is no doubt that the British owed a considerable part of their success in the guerrilla war to the $\mathrm{MI}$, though they could never catch the Boer for mobility.

9. Supplies and Sanitation. During the first phase of the war the Army Service Corps and Army Medical Corps functioned very inadequately because of the unfamiliar conditions in South Africa, such as long supply lines, often disrupted by the Boers, unexpected high battle losses and poor sanitation. Diseases were rampant, for most of the natural water become polluted because of access by men and their animals and because of the fighting. Two weeks after the siege of Cronje's camp close to Paardeberg dysentery reached epidemic proportions among the British army at Bloemfontein.

Both Corps were greatly expanded during the war and many improvements were introduced, as indicated in many pages by Stone. Nevertheless, sanitation in camps remained a big problem, which was only partially solved; better water filters were introduced but not always available. Stone states (p.101) that the British lost 20000 dead, of whom no less than two thirds died through disease, far more than losses in the fighting. Losses on the Boer side were even worse: of 24000 who died during the war, only 4000 died in combat, the remaining 20000 victims were prisoners of war and largely noncombatants in concentration camps. This is the sorriest record of the war. The camps for non-whites were worse; 14000 died there (Stone p.100).

10. Transport by Ship. Some mentions (p.18) the justifiably British pride in their achievements in transporting overseas many thousands of men and animals and equipment to and from South Africa, including prisoners of war to faraway islands and back. This success was due to the large British merchant navy. The recent transport of troops from the USA to Cuba in 1898 had been far more satisfactory. But Stone does not mention that transport ships were far from comfortable, that many ships were very dirty and riddled with vermin, so that they were little better than hell for prisoners of war and animals, among whom the mortality rate was high after a long sea voyage.

11. The Guerrilla. The regular war ended with the British occupation of all towns and railways in the Boer republics which were hurriedly annexed. Contrary to general expectations the war was continued by the Boers as a guerrilla war ${ }^{2}$. Again the GS was compelled to employ entirely new tactics. Their answer was (a) to construct blockhouses on 8000 "kopjes" to guard 3700 miles of railways and barbed-wire fences; (b) to introduce flying columns; (c) to conduct drives; and (d) to introduce concentration camps for civilians.

Stone acknowledges the first three achievements, but deems the drives more successful than the blockhouses and columns, although not decisive in terminating the guerrilla war. I think that in the long run British counter-guerrilla warfare was successful, as the Boers lacked the resources to replenish their men and arms.

The concentration camps operated far from satisfactorily and did not stop the guerrilla. Stone refers to the Fawcet Ladies' Commission which criticised the camps severely and effected considerable improvements, so that its Boer nickname, the "Whitewash Commission" was undeserved. I am of the opinion that during 1902 the mortality rate in the camps declined substantially and that the main fear of the Boer Bittereinders was not the situation in the camps, but the increasing aggressiveness of the Blacks, which is ignored by Stone.

He calls the blockhouses a unique measure, not to be repeated - unique because the Boers lacked the artillery which could have destroyed the blockhouses easily. He refers to the successful Boer tactic of charging in spread formation, firing from the saddle in "Arab fashion", which had a great effect on morale. I note that this tactic was also discontinued, because the horse was soon phased out in combat due to the increased firepower (machine guns) and was replaced for transport purposes by motor lorries.

Stone remains silent on the significance of intelligence (information) supplied by blacks and whites, regarding the deployment of Boer commandos. A Norwegian volunteer with De la Rey, Igvald Schrodër-Nielsen, writes: "A million Black eyes watched us day and night to report us to the British". Numerous National Scouts assisted the British effectively. 
Stone refers (p.101) to the economic aid given to the annexed republics by the British Government. To me this is the first example in history of aid being given by a victor to the vanquished, in South Africa not only because of the desire to welcome the ex-republicans into the British Empire, but also because of a feeling of guilt $-\mathrm{a}$ phenomenon with victors - regarding the scorched-earth policy and the concentration camps.

\section{The Post-Boer War Period}

Stone devotes the following and last two chapters to British military reforms after the lessons learnt from this war. These were recommended by Roberts during 1900-1903 and several of his best generals, such as Allenby, Ian Hamilton and McDonald, as well as by the able Secretaries of War, Brodrick (1900-1903), Arnold Forster (1903-1906) and Haldane (19061912). They persevered with these reforms even though hampered by (1) conservatism, (2) parsimony, (3) priority given to the Navy and the colonies and (4) absence of conscription.

1. Conservative Attitude. Many officers were and still are conservative, adverse to discarding previously favoured arms and tactics. Artillerymen disliked to disperse their guns under cover and camouflage or divide them into sections instead of batteries, because they remembered the Woolwich saying "one gun is no gun". Cavalry stuck to shock tactics and serried charges with lance and sabre instead of using rifles and fighting dismounted.

Stone also refers to the changes in warfare after Roberts and Arnold-Foster left, particularly as a consequence of experiences during the Russo-Japanese War (1904-1905). That war was waged on a much larger scale than the Boer War and its impact was greater. The War in Asia introduced aspects such as entrenchment, so disliked by British Mounted Infantry, the use of machine guns as well as a reaction to the Boer War tactics manifest in the increased use of bayonets, shock charges (after the Cossack example) and closer files in the attack. For some years the lance returned into use with the British Cavalry and cavalry changes and closed infantry files were reintroduced under the influence of Continental countries that had not fought a Boer War. The reaction worked itself out soon after the commencement of World War I.
2. Parsimony. The British Parliament was less generous with military expenditure than parliaments of the large Continental powers. Brodrick had to leave because his reforms were thought to be too expensive, but his two successors succeeded in carrying out army reforms without overstraining the military budget.

3. Navy or Army? Prior to the Boer War, Navy interests dominated, because the Navy had to defend the mother country as well as lines of communication with the Empire overseas. Accordingly the army had to be small. From 1902-1914 interests of the Army assumed more importance and Navy interests were less emphasised because of the mounting menace from Germany, especially after the Entente Cordiale with France, and after 1905 even from Russia. The Army prepared for warfare on the Continent, and orientated itself on the French and no longer on the German army.

4. Expansion of the Army. The Boer War had depleted Britain and the Dominions of the military and horses and proved that the Army had to be modernised and much expanded. General conscription was advocated by most reformers and Stone examines the arguments for and against it (p.149). Conscription was only introduced in 1915 whilst World War I was in progress. Military qualities were improved: after the Boer War army officers had to become more professional and the pay of military men was increased from £200 to $£ 300$ a year for officers. They were better educated and the number of illiterates and semi-literates among them declined dramatically.

On p.155-156 Stone ends his extensive survey of military reforms in all the arms and at all levels with the words: "The (high) quality of the British army in 1914 can hardly be credited solely to the influence of the Boer War. But if one looks at all the details in the decade following the South African (war) its importance is difficult to overestimate."

His work is excellent, but I miss a concise summary of his detailed study, an overview of strategic aspects of the war and an index.

* Dr C. de Jong (Rtd), formerly professor of Economic History at U.N.IS.A. 


\section{FOOT NOTES}

1. Stone praises Boer markmanship which outclassed the British, even after the Boers had to discard their Mausers because of lack of ammunition and when they had to resort to their enemy's rifle, the Lee-Metford. Factories in India produced expanding or soft-headed bullets, intended for natives, called the dum-dum, and sent thousands of cases to South Africa. However, this use was not allowed. Sir Henry Brackenbury made the sobering statement that the dum-dum was not used, not because it had been forbidden by the Hague Convention in 1899, but because it fouled rifle barrels (Stone p.68). British and Boers accused one another of using the dum-dum, but, in reality, a metal-mantle bullet which strikes a target at a short distance can have the same effect as an expanding bullet.

2. The word guerrilla is generally misspelled as guerilla or guerila and wrongly used. It is the diminutive of the Spanish guerra "war" in English) and means small war (German: Kleinkrieg, Dutch and Afrikaans: sluipoorlog). Guerrilla became a popular term during the Spanish resistance against Napoleon I. In the term guerrilla war the addition of "war" is superfluous. It should not be used in the sense of a guerrilla fighter, though this has now become standard practice (C. de Jong). 